\title{
Ethnologies
}

\section{Collective memory and cultural identity}

A comparative study of the politics of memory and identity among Israelis of Polish and Tunisian descent

\section{Giorgia Foscarini}

Volume 39, numéro 2, 2017

Échanges d'histoires, passages d'expériences et jeux de la mémoire Memories at stake: Sharing stories and exchanging experiences

URI : https://id.erudit.org/iderudit/1051665ar

DOI : https://doi.org/10.7202/1051665ar

Aller au sommaire du numéro

\section{Éditeur(s)}

Association Canadienne d'Ethnologie et de Folklore

ISSN

1481-5974 (imprimé)

1708-0401 (numérique)

Découvrir la revue

Citer cet article

Foscarini, G. (2017). Collective memory and cultural identity: A comparative study of the politics of memory and identity among Israelis of Polish and Tunisian descent. Ethnologies, 39(2), 81-98. https://doi.org/10.7202/1051665ar

\section{Résumé de l'article}

L'objectif principal de cet article est de fournir un compte rendu préliminaire des résultats de mes recherches de terrain sur l'identité et la mémoire des troisième et quatrième générations d'Israélites d'ascendance ashkénaze et mizrahi, notamment d'origine polonaise et tunisienne. Les questions sur lesquelles je me concentrerai sont: Comment les identités israéliennes de troisième et quatrième génération ont-elles été construites dans le temps et dans l'espace? Et comment la génération actuelle de jeunes Israéliens s'attache-t-elle à son patrimoine culturel, si tel est le cas, dans sa tentative de comprendre et de construire son identité actuelle? L'influence du passé historique d'Israël et de ses mémoires de migrants sera analysée en relation avec le processus de construction identitaire des deux groupes, et la manière selon laquelle ces souvenirs ont été intégrés ou non dans le récit national israélien. 


\section{COlleCtive MEMORY AND CULTURAL IDENTITY}

A comparative study of the politics of memory and identity among

Israelis of Polish and Tunisian descent

Giorgia Foscarini

Ca' Foscari University of Venice

The main aim of this paper is to provide a preliminary account of the results of my research, still ongoing, on the identities and memories of the third and fourth generations of Israelis of Ashkenazi ${ }^{1}$ and Mizrahi ${ }^{2}$ descent, in particular of Polish and Tunisian origin. This paper will mainly focus on the following questions: how have third- and fourth-generation Israeli identities been built over time and space? how are these identities related both to Polish and Tunisian cultural heritage, if at all, in the attempt to build today's Israeli identity? and if those migrant memories are not mustered, what other points of reference and memories are mobilized to build one's identity in today's Israel? I will thus consider the influence of Israel's past and of its migrant memories on the identity-building process of the two groups, their mutual relations as well as their relation to the main Israeli national narrative. This identity building process, which is by no means linear, has been affected not only by Israel's wider national narrative, but also by the individual, familial and communal memories of the two groups. Therefore, it will be of particular interest to see on which experiences this process is focused, and through which means it is expressed.

\section{Questioning the Ashkenazi-Mizrahi divide through a comparative analysis}

I am considering Israelis of Tunisian and Polish origins as representatives of the primary ethnic division within the Jewish Israeli population: Jews whose parents immigrated to Israel from Europe and America (Ashkenazim)

1. Ashkenazi Jews will be here considered as those Jews whose parents immigrated to Israel from Europe and America.

2. Mizrahi Jews will be here considered as those Jews whose parents immigrated to Israel from Asia, North Africa and the Middle East. 
and those of Asian, Middle Eastern, or North African origin (Mizrahim) (on ethnic divisions see: Barth 1998; in Israel: Sasson-Levy 2013; Smooha 2002; Yiftachel 2006).

The choice of comparing two different groups requires, however, an explanation of the comparison method adopted. According to sociologist Cécile Vigour "it is important to keep in mind that comparing encompasses at the same time the act of assimilating and of differentiating, in relation to a criterion" (Vigour 2005: 6-7). While dealing with a sociological analysis it is thus necessary to clarify the comparative principles around which our work is devised. In our case, we are discussing the phenomenon of immigration and integration in Israeli society of two groups of different geographical, ethnic, social and cultural backgrounds, in relation to their awareness as a group, and the relationship they entertain with their past. But why is using comparison as a method interesting in our case? Comparing helps us to put into relation social phenomena that usually wouldn't be related to each other for different reasons, in this case political, by shifting the focus from one single perspective to multiple points of view. In particular, the choice of Israelis of Polish and Tunisian descent can be explained for the former by the iconic role played by Polish immigrants and by Poland in defining ${ }^{3}$ Israeli identity and culture before and after the war, as the birthplace of many of the founding fathers of the Yishuv, and then as the country where the Holocaust took place for the most part. Concerning Israelis of Tunisian descent, it is interesting to consider a group that has been, so far, less studied, in comparison to other groups hailing from North Africa and the Middle East (e.g. Moroccan or Iraqi Jews), that had a peculiar relationship with colonialism, and that, as the only case in North Africa, was touched by Nazi occupation and the Holocaust. ${ }^{4}$ Our hypothesis is that the analysis of two distinct groups, with different ethnic origins, cultural and religious

3. In this respect see the exhibition "From Poland we came... the contribution of Polish Jewry in building and developing the state of Israel, "curated by Batya Brutin, Ewa Wegrzyn and Katarzyna Odrzywolek.

4. In this case it will be particularly interesting to consider how a pillar of Israeli identity, such as the Holocaust, integrated in Israeli memory eminently from an Ashkenazi standpoint, was at first accepted as such in the Mizrahi narrative, only to be reclaimed later on through a Mizrahi appropriation of its narrative. It is to be noted that also Libya was, to a certain extent, touched by the Holocaust, being an Italian colony (1911-1943).

Regarding the different stages of Holocaust memories' integration in Israeli society, see: Ofer 2009; Shapira 1998; Yablonka 2003, 2016; Yair 2015 and Zerthal 2005. 
backgrounds and migrant histories, not only will allow for a more general understanding of the integration dynamics in a multi-ethnic society, such as Israel, but will also serve to highlight the steps in the identity and memory building process of the two groups considered according to the historical, socioeconomic and political developments in relations to Israeli history up to present time. By analyzing how the past is remembered, it will be possible to appreciate how the narratives of different groups, Ashkenazim and Mizrahim, were built and received within the Israeli society at large, thus better understanding how present-day Israeli identities have been displayed and shaped. Furthermore, it will be explored how the construction of the past and the creation of a national master narrative, through a process of invention, appropriation, exclusion and reception, affected the relationships of remembrance and of power within the two groups considered and the society where they integrated.

The sources considered in our work are both primary and secondary sources, the former consisting of in-depth interviews, mainly conducted by the author or retrieved in different archives, of personal journals and diaries, of testimonies, and of literary production, while the latter include archives of cultural and citizen's associations, newspaper and magazine articles, websites and Facebook pages dealing with the cultural heritage and memory of the two groups concerned.

\section{Memories and generations}

The concept of 'collective memory,' intended as the shared representations a given group has of its past in relation to its present, links individual memories to bigger networks of memory, such as families, organizations, nation-states. ${ }^{5}$ In fact, these networks help to frame and locate individual memories, by making sense of them through a collectivity (Halbwachs 1994, 1997). Accordingly, it is interesting to consider in which ways the emergence of migrant collective memories is relevant to the evolution of Israeli society, to its growing fragmentation and to the decline of other social and political forces and groups, such as, for instance, political parties and trade unions, that used to constitute its foundation. In this sense it seems that Israel is heading more and more in the direction of being a "diasporic state," made up by the juxtaposition of many different identities (Confino 1993), instead of the Zionist ideal of kibbutz

5. On the concept of group, be it defined by its ethnicity, religious orientation or class, see Anderson 2006; Brubaker and Cooper 2000, Strauss 2017. 
galuyiot, ${ }^{6}$ with a unified Jewish-Israeli identity. Moreover, the creation of a national identity though different generations cannot be reduced solely to memories of migration, as each generation is shaped not only by the interactions between different reference groups, such as the family or the ethnic group of reference, but also, and mostly, by the social and political events marking its youth (Mannheim 1928). Along this line, to be integrated into the identity building process of a given society, the past must be shared and acknowledged by multiple groups and by the following generations, becoming a "sociocultural mode of action" (Confino 1997: 1390). We can thus consider the study of collective memory as the study of the interactions between distinct representations and narrations of the past put forward in the present by different groups in a society (Anderson 2006).

Going back to the case study of Israel, it is now clear why a society constituted by many, often divergent, groups and ethnicities needed a solid collective memory and cultural identity as the glue that would allow it to come into being and to exist (Kimmerling 2001; Shapira 2012). In this sense, we can define cultural identity as the crystallization of a collective experience that sets the boundaries of a given group, defining it, as the starting point from which in each era a given society reconstructs its past, within its contemporary frame of reference (Assman and Czaplicka 1995). Collective memory is thus no longer only the 'natural' outcome of a group remembering its past. Even more so in the Israeli case, the creation of a unified collective memory has a political meaning, being closely linked to the creation of national identity, in a nation building context where 'the nation' comprised very different groups of immigrants that, initially, had little in common except for their Jewish identity. What is interesting is that this unique common trait shared by all immigrants to the new state of Israel, i.e. the religious affiliation to Judaism, was in a way flattened and reduced to something prominently cultural, rather than specifically religious. This happened especially during the first years of the state, which were crucial to the creation of the new Israeli identity, that, as per Zionist ideology, was supposed to be secular. This is mirrored by many interviews, where most respondents do not mention religion as an important trait in their identity, and, in case they do, it is precisely as a link to a pre-Israeli/ Zionist identity and memories.

6. Kibbutz galuyiot: (heb: ingathering of the exiles) is a core idea of the Zionist ideology, and later, of the state of Israel itself, having as its main aim to establish a homeland for the Jewish people in the Land of Israel. 


\section{Creating a new cultural memory}

To address the topic of memory in Israel, it is necessary to gain a better understanding of the historical and social circumstances that led to the formation of the Israeli national community. With the aim of establishing a shared national narrative and considering the creation of a Jewish state as the only possible ending to a long history of persecution and discrimination, the Zionist movement ${ }^{7}$ started to produce and objectify a knowledge and a set of practices that would serve as the grounds for the formulation and transmission of the future Israeli cultural identity and collective memory. According to Zionism, the idea of return to the motherland was essential. Therefore, Israel's founding fathers borrowed a religiously preserved collective memory (Kimmerling 2001), that of Zion, ${ }^{8}$ and readjusted it to fit the secular character of Zionism. This was meant to encourage Jewish immigration to the Land of Israel, and, as a consequence, the Israeli calendar was punctuated with holidays and memorial days chosen to remind Jews of their traumatic history, both ancient and contemporary (Zerubavel 1996). Most of these memorial events supported a rhetoric of detachment from Jewish life in exile ( $g a l u t)$, considering it as a completely negative historical phase, in between the antique and the modern phases, regarded as positive by Zionism. A normative self-image of the group was thus created, according to a Hebrew/Jewish/Zionist ${ }^{9}$ system of values that would be able to supply knowledge and symbols to structure the future Israeli society. In this way, a Zionist reinterpretation of the Jewish Biblical past was included in Israel's habitus and national narrative, adding up to build what Zubrzycki defines as "national sensorium": a set of various practices, crystallized in material culture and embodied in different performances, which helps render the abstract idea of the nation concrete for individual subjects (Zubrzycki 201: 22).

In the creation of such a master narrative, Zionism proceeded by ignoring and suppressing memories and facts that were in conflict or outside its own interpretation of the past. A good case in point is provided by the reception and integration of the big immigration wave that occurred right after the establishment of the state, between 1948 and 1952, called the

7. Jewish nationalist movement that had as its main goal the creation and support of a Jewish national state in Palestine, considered as the ancient homeland of the Jews.

8. In this context, Zion is intended as a synonym for Jerusalem and for the Land of Israel as a whole, viewed in an eschatological dimension as the place where the entire Jewish people was to return.

9. On the distinction between Jewish, Hebrew and Israeli see Regev 2000. 
'great Aliyah'. ${ }^{10}$ Before 1948, Jews coming from Eastern Europe represented the dominating ethnic group in the Yishuv, ${ }^{11}$ and, being the most educated and ideologically oriented among immigrants, they also came to constitute the political and cultural elite of the future State of Israel. The migratory waves that occurred from 1949 onwards, originated mainly from North Africa and other Arab countries, and permanently changed the European outlook of the newborn Israeli state, by forcing it to assimilate a substantial number of people coming from a different cultural background and religious tradition too.

To cope with such a challenge, the Israeli establishment adopted the integration doctrine of the "melting pot," where Jews from different diasporas would come together to create a "uniform new Israeli persona and personality" (Kimmerling 2001:97). To achieve such an end a number of state agencies - notably the educational system, youth movements and the army - were recruited to instill the new national ethos and to pass on a historical narrative based on the concept of the shlilat ha-golah ${ }^{12}$ and on a newly invented Hebrew-speaking, Israeli tradition. It should be remembered that the basis for such a discourse was, and partly still is, an exclusively European and Zionist interpretation of a Jewish past that dismissed completely the possibility of an Arab context to Jewish history, subordinating altogether Arab Jews to an allegedly 'universal,' but in reality, Eurocentric, Jewish history (Shohat 1999). This hegemonic discourse, based on a supposed equality among all the members of the newly created society, denies "the possibility of racial or ethnic inequalities among Jews" (Sasson-Levy 2013), thus putting everyone on the same level, when, in reality, a clear hierarchy in terms of cultural legitimacy of one's origin was put into place. Consequently, new immigrants, especially those coming from North Africa and the Middle East, according to a binary and orientalist mindset deployed by the elite of the newborn state of Israel, were asked to conform to a national narrative they did not contribute to create, and where their Arab origin positioned them at the 'wrong pole' of the newly

10. Aliyah (heb: sing. - ascent; pl: Aliyot), is the immigration of Jews from the Diaspora to the Land of Israel. It should be noted that this migratory wave comprised also of a large number of refugees and Holocaust survivors from Europe immigrating to Israel after the end of the war (see Shapira, 2014). However, there was some bias, notably running through ethnic lines, in the integration policies carried out towards incoming immigrants in that period.

11. Yishuv (heb: settlement), is the term which refers to the settlements of Jewish residents in the Land of Israel, prior to the establishment of the State of Israel.

12. Shlilat ha-golah (heb: negation of the Diaspora): Zionist concept used to explain the impossibility of Jewish emancipation in the Diaspora. 
created social hierarchy (Khazzoom 2003).

\section{Israelis of Tunisian and Polish descent: cultural memory and its transmission}

It is in such a historical and social context that our fieldwork can be placed. Interviews were conducted according to a semi-directive method, and the sample, around 20 people, was selected through the snowball sampling method, and by contacting cultural and community associations dealing with Polish and Tunisian cultural heritage. Thanks to this method, I got the chance to interview people of different age groups, sometimes belonging to the same family, thus gaining a trans-generational perspective as well. This allowed us to appreciate how their perception of what it meant for them to be Israelis of Tunisian or Polish origin developed throughout. It is to be remembered that both groups considered were characterized by different migration histories and by a certain degree of heterogeneity at the moment of the depart from Tunisia or Poland and that this was given by a number of factors, among them: ethnic, geographical and religious. ${ }^{13}$

In particular, migration of Tunisian Jews began around the mid 1940s and continued up to the early 1960s (Sebag 1991). In the case of the interviews considered for this paper, respondents with a Tunisian background immigrated to Israel, or rather their family did, right after Israel's independence, in 1948, or in the following migratory wave between 1954 and 1956, when the struggle for the independence of Tunisia (July 1957) was more prominent and almost all Tunisian Jews who stayed in the country, left, either for Israel or France.

On the other hand, immigration of Polish Jews can be traced in all aliyot from the late $19^{\text {th }}$ century to the establishment of the state, and even afterwards. In almost all of these migratory waves, especially from the second aliyah on, Polish immigrants constituted one of the largest groups. ${ }^{14}$ Furthermore, three more waves of Polish immigrants arrived in Israel after 1948: one in the wake of the Holocaust (1948-51), as a part of the Great

13. When considering Jews of Tunisian origin, ethnic and geographical differences must be taken into consideration (Grana vs Twensa; urban vs rural) (Sebag 1991). Whilst considering Jews hailing from Poland, differences are to be located more along religious and class lines (assimilated, urban Jews vs rural Hassidic Jews) (Cheniavsky).

14. Israel CBS, Jewish Population 1931-1954, November 1995, in Cheniavsky, Irith, "Does Poland lie on the Mediterranean Coast? 'Polish Jews' and their descendants in Israel." 
Aliyah; another in 1956-60, when legal emigration from Poland was still possible; and the last wave in the years between 1968 and 1969, where the last remaining of the Polish Jewish community left the country mostly for Israel. Up to this point, I managed to interview people whose families came to Israel both with the first aliyot, between 1924 and 1939, therefore, before the Holocaust, and during and after World War II and the Holocaust, up until the 1950s, mostly as war refugees or Holocaust survivors.

The general trend which emerged by analyzing the collected interviews, and through some periods of participant observation in organizations in charge of preserving the memory of both communities (Amit, Federaziah ha-'olamit shel yahadut Tunisiah be-Israel, Centre mondiale du Judaïsme Tunisien, Association of Polish Jews in Israel, Beit Lohamei Hagetaot, and others) is that representatives of the second and third generations (people around $40-50$ years old or older) appear to be more interested in preserving their family's memories ${ }^{15}$ and cultural heritage, be it Tunisian or Polish, than the younger generations. This assumption is confirmed by the following interview excerpts, where the people interviewed all belonged to the second or third generation. From the conversations and the participant observation, four main themes emerged in relation to memory and identity issues:

- Interviewees' participation in activities community/ethnic group related (food, language, cultural events etc.);

- Memory/remembrance of the Holocaust;

- Participation or willingness of the interviewees to undertake a heritage trip or memory activities;

- Family's influence and feelings towards the cultural heritage of one's family's country of origin;

I will here focus on one of the themes which emerged during the interviews: the family influence and feelings towards the cultural heritage of one's family's country of origin, vis-à-vis the 'new Israeli identity', paying particular attention to the ethnic implications of this topic.

Firstly, we will look at the life story of a woman, Galit (50 years old). Her background is particularly interesting because she is the daughter of a mixed Polish-Tunisian couple: her father was born in Israel of Polish parents (Cracow/Lviv), while her mother was of Tunisian origin (Gabes). Galit,

15. Here the term memory is used with its vernacular and everyday meaning, that of personal recollections and souvenirs. This is the reason why it is mostly used in its plural form. 
though identifying herself as an "ashkenaziyah" (an Ashkenazi woman), ${ }^{16}$ with all the implications that such a self-labeling entail (Sasson-Levy, 2013), talked to me mostly about her Tunisian heritage, how she perceived it as a child in the 1960s, how she perceives it now, and about her intentions of preserving it by researching the history of her family. In relation to the hegemonic role of Ashkenazi identity in Israel's culture, both when she was a child and nowadays. She said:

At that time, there was conscious and unconscious discriminations, social, employment, anything... the culture of the young Israeli society was Ashkenazi, and if you wanted to integrate you couldn't say: 'I have some kind of... [Tunisian/Sephardi background].' I have seen it from my own experience when kids knew my mom was Tunisian they wouldn't make friend with me anymore. Because that was the atmosphere back then, and it came from above, the government, the leaders, I am sure you read that Israel was established as a Western country and whoever had a different culture should not show it, one should be 'tzabar, ${ }^{17}$ you should have the culture that was consolidated in Israel without any reference to the Sephardi culture. And that's how I grew up you know... it's something I am not inventing for you, it has been written in books. I basically went out [of the house] and behaved as a Polish little girl, and, honestly, I feel bad about it because it was only at university when I did the last year, that I started to ask more questions (about my Tunisian side of the family). Until then I thought that the Tunisians were kind of primitives, they were not as cultured as the Europeans. What I got (from the Tunisian side) is a part of myself, part of my heritage, but I did not get to share it, and again it's nothing that was talked about, it was said (that society was Ashkenazi shaped), it was taken for granted, it was the society. So, I feel bad that I didn't check and that I didn't learn about this tradition before, because when I got to talk to and interview women from my family it was almost too late, they were in their seventies or eighties and one aunt died before I got to interview her. ${ }^{18}$

From Galit's and other interviewees' statements, we understand that the master narrative in Israel, not only back in the 1950s and 1960s, but also later on, was created through a process of subordination and exclusion

16. In another part of the interview she pointed out the fact that for her it was easy to be considered as an ashkenaziyah thanks to her looks which were very European. In fact, she is blond with blue eyes.

17. Tzabar (heb: prickly pear), is a Hebrew term that refers to a Jew born in Israel, a native-born Israeli.

18. Interview of the author with Galit, Tel Aviv, March 28, 2017. 
of any cultural heritage and tradition not conforming to the hegemonic cultural norm established by Zionism. Mizrahi culture in particular was marginalized, as it was considered as "primitive," vis-à-vis other cultures and heritages hailing from Europe, such as the German or the Polish one itself, that were used as the cornerstone for the creation of the "new Israeli identity." By accepting the latter, new immigrants had to choose between their 'old' culture and the 'new' culture and to redefine themselves in relation to the paradigm of "Israeliness" (Kimmerling 2001). Especially in the first decades of the state, the coexistence of different traditions was considered threatening to the idea of a homogeneous Jewish nation as conceived by the state's ruling class (Smooha 2008). For this reason, immigrants from North Africa and the Middle East were asked to choose between 'Jewishness' and 'Arabness', traits that were posited as mutually exclusive in the Zionist narrative (Shenhav 2006), and to curb all memories and cultural expressions of their Arab identity to fit in. Moreover, the fact that Galit is more interested in her Tunisian heritage proves the invisible and 'taken-for-granted' character of Polish cultural memory and identity in today's Israel. When talking about what Polish heritage could mean to her, she reported leaving her husband the task of researching about the genealogy and history of the Polish side of the family. In defining "Polishness" she was always quite vague, and she ended up associating it with Israeli culture, generally speaking:

You know I haven't got much... most of the heritage I got is the food my mom cooked... my (Tunisian) mom, she cooked Polish food with some Tunisian spice (chuckles). [...] You know, I don't know what Polish heritage may be. My dad was born in Israel and my husband's parents were born in Israel both of them. So, the food is... whatever is food related... it is very similar to the Israeli one, what my mother is preparing for Passover, except for a few special Tunisian dishes, is what the other grandmother (Polish one) is preparing. So... I don't know how many kids really have a Polish heritage... I don't know, it's an interesting question, I never thought about it, there is no Yiddish, or a few words here and there at best. The only thing that the boys did and now also my girl is doing is that they learned French, because my mom's first language was French, so they were happy to talk with her in French. Other than that, is kind of Israeli you know? It is all one (culture)... Maybe the melting pot did succeed in a way... maybe... because I can't think of anything specifically Polish... you know maybe that "fiddler on the roof" ... but maybe it's Russian.... in any case you don't see it anymore. I don't know what's Polish culture... ${ }^{19}$

19. Interview of the author with Galit, Tel Aviv, March 28, 2017. 
These considerations led us to think that "Polishness" may be considered as an unmarked trait today in Israeli society (Sasson-Levy 2013). Along with Brekhus "the distinction between marked and unmarked elements is heuristically valuable for analyzing social contrasts (...). The concept of 'social markedness' [is used] to refer to the ways social actors actively perceive one side of a contrast while ignoring the other side as epistemologically unproblematic" (1996: 500). Most of the interviewees of Polish background did not recognize having some sort of specific Polish heritage and were pretty insecure about what this may mean to them, except for a few recurrent elements such as the Holocaust, which is an element shared in the memory of all Israeli citizens (Yair 2015), the Yiddish language (which none of them spoke), and the stereotype of the Polish-Jewish mother. The majority of the respondents were born in a mixed family, and when asked to identify with the cultural heritage of one side of the family, they always chose the non-Polish 'side', be it German, Moroccan or Italian, as the more interesting one. The Polish side generally considered as not problematic, is associated with Israeli culture tout-court, and thus not considered worthy of too much attention. By claiming that Polishness is an unmarked character in today's Israel, I mean that this character represents "the vast expanse of social reality that is passively defined as unremarkable, socially generic [...]" (Brekhus, 1998 p. 35), and for this reason hegemonic. To most of the interviewees, Polish equaled Ashkenazi and there was for them no difference between the two. Furthermore, I assume that it is specifically Polishness, more than other kinds of Ashkenazi backgrounds to have gained this role of invisible and unmarked character in Israeli society, as, in other interviews, respondents with a non-Polish Ashkenazi background, German for instance, were more likely to highlight it as specific and marked, with respect to the Polish one. In Galit's case, it was the Mizrahi-Tunisian background to be considered as different and thus, to her, more interesting and worthy of investigation and in-depth research. Starting from a 'safe' position of defining herself as an "Ashkenaziyah" she decided to explore her Tunisian heritage and memories, proving, to some extent, that ethnic boundaries are still quite strong in Israeli society.

Regarding the transmission of Tunisian cultural heritage and traditions, one of the most interesting elements is surely language. Galit explicitly said that her kids were going to learn French to communicate with their Tunisian grandmother. The importance given to the French language, and thus culture, within the memories and self-representations of Israelis 
with a Tunisian background calls attention to the fact that many Jews who immigrated to Israel from Tunisia posited their culture as chiefly French. In this respect, the same remark was made to me by Shira, a woman in her sixties, whose parents immigrated from Nabeul (Tunisia) to Israel in the 1950s. According to her life-story, Shira has always been extremely interested in her own cultural heritage, identifying herself as Tunisian with a French education, in this respect she told me:

Immigrants from Tunisia and Algeria are to be considered as Europeans, rather than Mizrahim. French colonialism had laws distinguishing Jews from locals in Tunisia, and indeed the French called Tunisian Jews 'Juifs Arabes'. My father had a successful hosiery business in Nabeul, and he had strong connections both in France and in Israel. ${ }^{20}$

By saying so, she claimed a higher social and cultural status for immigrants from Tunisia, by refusing to be tagged with the general label of Mizrahi, that she considered as derogatory. While talking, Shira put a lot of emphasis on the fact that, even if her family was well integrated in Nabeul, she and her siblings maintained all along their Jewish/French identity, thanks to the schools of the "Alliance Israélite Universelle." By underlining that her main cultural reference was French, she revendicated for herself a cultural superiority, granted precisely by French language and culture, with respect to other immigrant Easterners (e.g. Moroccans), in this way applying herself an orientalist and ethicizing paradigm to immigrants that did not have that 'Western' asset in their cultural capital.

Nonetheless, Shira's relationship with her Tunisian-Jewish cultural heritage encompasses as well a strong commitment to preserve Tunisian specificity for future generations in Israel. This is shown on an individual level by the research she is conducting on the cult of female saints in Tunisia and the pilgrimages of Tunisian Jews linked to them. She went herself on a number of heritage and memory trips to Tunisia, first in 1996, to do the pilgrimage of Saint Lakhtar, and then later on, in 2000, when she organized a heritage trip for her family, and finally, when she returned to Nabeul with her mother and brother. ${ }^{21}$ After her last trip to Tunisia she reported having become religiously observant as a way to keep her Tunisian tradition alive and to honor her father. She also mentioned food and holiday celebrations, according to the Tunisian tradition, as a very important way to keep her heritage alive and pass it on to her children and grandchildren.

20. Interview of the author with Shira, Jerusalem, March 27, 2017.

21. Shira and her family stopped traveling to Tunisia, as most Jews did, with the beginning of the Arab spring and the growing uncertainty on the political stability of the country. 
On a more communal level she is involved in the activities of the World Federation of Tunisian Jews in Israel (Federaziah ha-'olamit shel yahadut Tunisiah be-Israel), where she is a member of the organizational committee and as such, is involved in many different activities for the preservation of Tunisian cultural heritage in Israel (cultural events, publication of books, concerts, organization of heritage trips, etc.). For instance, they organize cultural events to celebrate and remember holidays typical of the Tunisian Jewish tradition, such as the trilogy of Tunisian winter holidays: rosh hodesh el-bnat, sh'oudat 'Ytrou and rosh hodesh Nissan or soirée de la Bchicha. ${ }^{22}$ These holidays are meant to commemorate and continue Tunisian tradition in Israel. The celebrations in general consist of a meal held within a communal celebration, where the members of the Tunisian community in Israel are invited, traditional Tunisian music is played and where the history and the traditional ways of the holiday are remembered. Her involvement in the activities of the Federaziah also includes an annual ceremony of commemoration for the Tunisian victims of the Holocaust, which has been held each year at Yad VaShem, since 2005. This ceremony, very similar to the ceremony held during the national Holocaust Remembrance Day, can be seen as an attempt of this association to include Tunisian cultural heritage and memories in a national framework where Holocaust and Holocaust remembrance play a great role in terms of legitimacy. By looking at Shira's interview we can notice that she is deeply engaged in carrying on the memory of her family in particular, and more broadly the memory of her Tunisian cultural heritage.

\section{Conclusion}

From the interviews, we can thus understand how the creation and passing on of Israel's collective memory and cultural identity constitutes a representation, and thus, a political issue. It is interesting to notice that "Polishness" is still regarded as an unmarked trait in Israel today. The majority of the interviewees do not recognize any sort of specificity in their Polish heritage and are pretty insecure about what this may mean to them. Accordingly, cultural associations dealing with Polish cultural heritage in Israel are scarce and mainly linked to Holocaust memory and remembrance.

Concerning the cultural heritage and memories of Israelis of Tunisian descent, as it emerged from the interviews, it is clearly more marked within Israeli society, than the Polish one. In particular, Jews of Tunisian descent

22. For further details see: http://www.terredisrael.com/comm_juive_Tunisie-accueil. php 
are more involved in the preservation and transmission of their heritage, as is demonstrated by the existence of numerous cultural associations and activities related to it. It can be noted that in the Tunisian case religion is closely linked to the preservation of tradition; firstly, when Shira mentions the fact that she started practicing religion again after multiple trips in Tunisia, looking for memories and traces of her family's history; and secondly, by keeping alive the celebration of the trilogy of Tunisian winter holidays, that intertwine in a very close way Tunisian tradition and Jewish religion.

As for the link between Israel's national narrative and its identity, it was created, and to some extent still exists, by putting in the background some memories and traditions, notably those originating from a Mizrahi/ Eastern heritage and by putting in the foreground others, hailing from an Ashkenazi/Western one (Zerubavel 1995; Ben Amos 2010). In this sense, for many, nowadays, the narrative of an Israeli identity as Western, modern and secular is not in any way limited to Ashkenazim alone and it is actively shared by many Mizrahim (Sasson-levy 2013). This was confirmed by numerous interviewees of Tunisian descent, such as Shira, that refused to be labeled as Mizrahi and, in general, preferred to be associated with the French (Western) variation of Tunisian-Jewish culture, thus proving the powerfulness of ethnic boundaries set at the establishment of the state. It is in fact the group that gets to decide which representations of the past are accepted or refused by society that has the power to inform its collective and cultural memory. However, even if adjusting their being Mizrahi to a hegemonic Ashkenazi narrative, the various ethnic groups making up Israeli society are playing a major role in keeping open the negotiation of what is to be remembered (cultural memory), and by doing so they try to elaborate a more inclusive narration of the past according to their present needs (Schwartz 1982; Nerone and Wartella 1989; Liu and Hilton 2005). A good case in point is, as mentioned above, the revendication of a specifically Tunisian memory of the Holocaust. By organizing a commemoration event in the framework of a national and Ashkenazi established institution such as Yad VaShem, the Federaziah reclaims for Tunisian Jews a role in the creation of the narrative of one of the founding events of Israeli identity, by creating a Tunisian led narrative of the event, and by placing it in Yad VaShem, a major symbol of Israel's memory and identity.

In this sense, many questions are left open to tackle in a research aiming at addressing the role of memory and cultural heritage in the shaping of national identity in Israel nowadays. In particular one of the main questions 
left open, and only marginally addressed in this paper, is the role of the categories of Ashkenaziness and Mizrahiness, and to what extent they are still valid and useful to define present-day Israeli society. 


\section{References}

Amar, Marianne, Helène Bertheleu and Laure Teulières. 2015. Mémoires des migrations, Temps de l'histoire. Tours: Presses universitaires François Rabelais.

Anderson, Benedict. 2006. Imagined Communities. New York: Verso.

Assman Jan and John Czaplicka. 1995. "Collective Memory and Cultural Identity," New German Critique 65: 125-133.

Barth, Fredrik (ed.). 1998. Ethnic Groups and Boundaries; the Social Organization of Culture Difference. Long Grove: Waveland Press.

Ben Amos, Avner. 2010. Israël: la fabrique de l'identité nationale. Paris: CNRS Editions.

Bourdieu, Pierre and John B. Thompson. 1991. Language and Symbolic Power. Cambridge: Polity Press.

Brubaker, Roger and Cooper. 2000. "Beyond 'identity'." Theory and Society 20: 1-47.

Brekhus, Wayne. 1998. "A Sociology of the Unmarked: Redirecting Our Focus.” Sociological Theory 16: 34-51.

Calhoun, Craig. 1994. "Social Theory and the Politics of Identity." In Craig Calhoun, (ed.), Social Theory and the Politics of Identity: 9-36. New Jersey: Wiley-Blackwell.

Cheniavsky, Irith. "Does Poland lie on the Mediterranean Coast? 'Polish Jews' and their descendants in Israel." on line : https://www.academia. edu/16684253/Polish_Jews_and_their_descendants_in_Israel

Confino, Alon. 1993. "The Nation as a Local Metaphor: Heimat, National Memory and the German Empire, 1871-1918." History and Memory 5(1): 42-86.

- 1997. "Collective Memory and Cultural History: Problems of Method." The American Historical Review 102(5):1386-1403.

Gil, I. 2012. "The Shoah in Israeli Collective Memory: Changes Meanings and Protagonists." Modern Judaism 32(1):76-101.

Goldberg, Harvey E., Steven M. Cohen, and Ezra Kopelowitz. 2012. Dynamic Belonging: Contemporary Jewish Collective Identities. New York: Berghahn Books.

Halbwachs, Maurice. 1997. La mémoire collective. Paris: Albin Michel. 1994. Les cadres sociaux de la mémoire. Paris: Albin Michel.

Kimmerling, Baruch. 2001. The Invention and Decline of Israeliness: State, Society, and the Military. Oakland: University of California Press.

Liebman, Charles S. and Eliezer Don-Yehiya. 1983. Civil Religion in Israel:

Traditional Judaism and Political Culture in the Jewish State. Oakland:

University of California Press. 
Liu, James H. and Denis J. Hilton. 2005. "How the past weighs on the present: Social representations of history and their role in identity politics." British Journal of Social Psychology 44: 537-556.

Mannheim, Karl. 2008. Le Generazioni. Bologna: Il Mulino.

Nerone, John and Wartella, Ellen. 1989. "Introduction: studying social memory." Communication 11: 85-88.

Nora, Pierre. 1989. "Between Memory and History: Les Lieux de Mémoire." Representations 26: 7-24.

Ofer, Dalia. 2009. "The past that does not past: Israelis and Holocaust memory." Israel Studies 14(1): 1-35.

Regev, Motti. 2000. "To have a culture of our own: on Israeliness and its variants." Ethnic and Racial Studies 23(3): 223-247.

Resnik, Julia. 2003. "'Sites of memory' of the Holocaust: shaping national memory in the education system in Israel." Nations and Nationalism 9: 297-317.

Sasson-Levy, Orna. 2013. "A Different Kind of Whiteness: Marking and Unmarking of Social Boundaries in the Construction of Hegemonic Ethnicity." Sociological Forum 28(1): 27-50.

Schwartz, Barry. 1982. "The Social Context of Commemoration: A Study in Collective Memory.” Social Forces 61(2): 374-402.

Sebag, Paul. 1991. Histoire des Juifs de Tunisie : des origines à nos jours. Paris: Éditions l'Harmattan.

Shafir, Ghershom and Yoav Peled. 2004. Being Israeli: The Dynamics of Multiple Citizenship. Cambridge: Cambridge University Press.

Shapira, Anita. 1998. "The Holocaust: Private Memories, Public Memory." Jewish Social Studies 4(2): 40-58.

. 2012. Israel: a History. Waltham: Brandeis University Press.

Shenhav, Yehouda. 2006. The Arab Jews: A Postcolonial Reading of Nationalism, Ethnicity and Religion. Stanford: Stanford University Press.

Smooha, Sammy. 2002. "The model of ethnic democracy: Israel as a Jewish and democratic state." Nations and Nationalism 8(4): 475-503.

2008. "The mass immigrations to Israel: A comparison of the failure of the Mizrahi immigrants of the 1950s with the success of the Russian immigrants of the 1990s." The Journal of Israeli History 27(1): 1-27.

Somers, Margaret T. 1994. "The Narrative Construction of Identity: A Relational and Network Approach." Theory and Society 23(5): 605-649.

Strauss, Anselm. 2017. Specchi e maschere. La ricerca dell'identità. Nocera Inferiore: Orthotes.

Yablonka, Hanna. 2003. "The Development of Holocaust Consciousness in Israel: the Nuremberg, Kapos, Kastner and Eichmann Trials." Israel 
Studies 8(3): 1-24.

Yablonka, Hanna. 2016. Les Juifs d'Orient, Israël et la Shoah. Paris: CalmannLévy.

Yair, Gad. 2015. "Israeli existential anxiety: cultural trauma and the constitution of national character." Social Identities 20(4-5): 346-362. Yifatchel, Oren. 2006. Ethnocracy: Land and Identity Politics in Israel/Palestine. Philadelphia: University of Pennsylvania Press.

Vigour, Cécile. 2005. La comparaison dans les sciences sociales. Pratiques et méthodes. Paris: La Découverte.

Zertal, Idith. 2005. Israel's Holocaust and the Politics of Nationhood. Cambridge: Cambridge University Press.

- 2000. "From the People's Hall to the Wailing Wall: A study in Memory, Fear and War." Representations 69: 96-126.

Zerubavel, Yael. 1995. Recovered Roots: Collective Memory and the Making of Israeli National Tradition. Chicago: University of Chicago Press.

Zubrzycki, Geneviève. 2011. "History and the National Sensorium: Making sense of Polish Mythology." Qualitative sociology 34(1): 21-57. 